This item was submitted to Loughborough's Research Repository by the author.

Items in Figshare are protected by copyright, with all rights reserved, unless otherwise indicated.

\title{
Jives, jeans and Jewishness? Moral geographies, atmospheres and the politics of mixing at the Jewish Lads' Brigade \& Club 1954-1969
}

PLEASE CITE THE PUBLISHED VERSION

http://dx.doi.org/10.1177/0263775816644257

\section{PUBLISHER}

SAGE (@ the author)

VERSION

AM (Accepted Manuscript)

\section{PUBLISHER STATEMENT}

This work is made available according to the conditions of the Creative Commons Attribution-NonCommercialNoDerivatives 4.0 International (CC BY-NC-ND 4.0) licence. Full details of this licence are available at: https://creativecommons.org/licenses/by-nc-nd/4.0/

\section{LICENCE}

CC BY-NC-ND 4.0

\section{REPOSITORY RECORD}

Mills, Sarah. 2019. "Jives, Jeans and Jewishness? Moral Geographies, Atmospheres and the Politics of Mixing at the Jewish Lads' Brigade \& Club 1954-1969”. figshare. https://hdl.handle.net/2134/21085. 
Jives, jeans and Jewishness? Moral geographies, atmospheres and the politics of mixing at the Jewish Lads’ Brigade \& Club 1954-1969

Keywords: Youth , Gender , Religion , Moral Geographies , Atmosphere , Encounter

\begin{abstract}
This paper examines a series of anxieties about mixing at the Jewish Lads' Brigade and Club (JLB \& C) in Manchester, UK during the 1950s and 1960s, primarily focused on inter-faith activities, relationships and marriages. This paper explores how a powerful moral geography of gender and religion came to be shaped, regulated and negotiated at this youth work space. The concerns expressed by some adults over teenage encounters in the post-war city were articulated and understood through the notion of 'atmospheres', and this paper suggests how this idea and language captured some of the anxieties and emotions surrounding cultures of leisure at this time. This paper contributes an in-depth and sustained focus on the moral geographies of the post-war city in relation to young people, as well as addressing an important gap in scholarship on Jewish youthful religiosities. Furthermore, it pushes at ideas about meaningful encounters through the consideration of the JLB \& C as a meeting space and arena for visitors. Overall, the paper examines how the JLB \& C acted as both a mirror to the wider social changes of the post-war era, whilst also being an active contributor in shaping those same processes of social change.
\end{abstract}

\title{
Introduction
}

"Modern Jewish youth today jives, listens to pop records, watches 'telly', wears jeans and has Perry Como haircuts. There is nothing bad about these things...but they are not necessarily Jewish". ${ }^{1}$

This quote from the 1957 Annual Report of the Manchester Jewish Lads’ Brigade \& Club encapsulates the challenge that religious youth work faced in post-war Britain: to attract and connect with the 'modern' teenager and yet preserve and sustain a sense of religious identity. The national Jewish Lads’ Brigade (hereafter JLB) was founded as a voluntary uniformed 
youth organisation in 1895 and grew rapidly across the United Kingdom (Kadish 1995; Bunt 1975; on the linked Boys' Brigade see Kyle 2007). The aim of the JLB was youthful citizenship training, infused with a desire for inculcating English values and moral virtues through masculinist narratives of fitness, character and duty (Olsen 2014). In Manchester, one local JLB branch had an attached Club building as an adjacent leisure space where JLB members, who were mainly working-class boys from immigrant families, could utilise their free time playing games and sport rather than uniformed band practice and drill. It was not until the post-war period however, that this joined up Jewish Lads’ Brigade \& Club (hereafter the JLB \& C) and its embrace of post-war youth culture began to ring alarm bells for some within Manchester Jewry and beyond who feared the potential dilution of youthful religiosities. The JLB \& C’s embrace of jives, jeans - and even Perry Como haircuts - was overseen by the leadership of a non-Jewish professional youth worker hired in 1954 - Stanley Rowe. In just a few years following his appointment, the Brigade \& Club had grown nearly five times in size: from 84 teenagers on its books in 1954 to a staggering 400 young people regularly attending activities across an average week by $1959 .^{2}$ Although Rowe's presence challenged the JLB \& C's moral-religious framework until his departure in 1969, he completely revitalised and rejuvenated the organisation. One aspect of this re-invention surrounded gender politics and becoming a fully co-educational space. This experimental approach to gender-based provision mirrored the progressive mixing of Boys' and Girls' Clubs during this period (Collins 2003) yet diverged from the more conservative gender politics of the national JLB that did not create a separate organisation for girls until 1963, eventually merging in 1974. These unique dynamics of the JLB \& C in Manchester provide the starting point for this paper's discussion on the moral geographies of youth, gender, religion and encounters in the post-war city. 
At the heart of the JLB \& C's post-war reconstruction effort outlined above (see also Mills 2015) was an attempt to unite or blend two distinct atmospheres, named in multiple source material as a "Jewish" atmosphere that supported and sustained religious development and the more "adult" atmosphere of the city's tempting leisure spaces, such as coffee bars and beat clubs. Significantly though, these atmospheric qualities of popular youth 'haunts' were seen by many adults as hosting problematic behaviours and immoral practices. As these two atmospheres collided at the JLB \& C, a series of debates surrounding 'mixing' emerged, which this paper unpacks as its central focus. In so doing, this paper examines how a powerful moral geography came to be shaped, regulated and negotiated at the JLB \& C in Manchester under Rowe's tenure between 1954-1969. In exploring the wider politics of mixing at the JLB \& C and the mixed-sex encounters, inter-faith relationships and marriages it sparked, the paper makes three key contributions to geography and related disciplines.

First, the article contributes an in-depth and sustained focus on the moral geographies of the post-war city in relation to young people (Bugge 2004; Mills 2014; Stainton Rogers 2004). Whilst the study of 'moral geographies' is now a long-standing interest within disciplinary human geography with diverse foci (e.g. Cresswell 1996, 2005; Driver 1988), it remains an incredibly important framework, particularly in the context of studying young people's geographies (e.g. Aitken 2001; Valentine 1996; Kyle 2007). Second, although work on the 'new' geographies of religion has been growing over the last fifteen years (Kong 2001), there still remains scant work on Judaism and Jewish identities (although see Valins 2003a, 2003b for exceptions). This paper therefore also addresses this important gap in scholarship, building on recent studies of Jewish culture, youth and society by historians (e.g. Holdorph 2015; Smith 2007; Dee 2009; Spence 2004). Finally, the paper speaks to recent work in human geography on 'atmospheres’ (e.g. Anderson 2009; Finn 2016) and pushes at ideas about 'meaningful encounters' (Valentine 2008). Through a consideration of the JLB \& C as 
a meeting space between different groups of young people, I suggest it was a site of urban cross-cultural contact - a space where fears and hopes were articulated with direct reference to the youth club’s 'atmosphere'.

In terms of the paper's structure, the next section locates the above contributions more fully within relevant academic literature. The discussion is then structured in four analytical sections that chart the JLB \& C's quest for the 'right' atmosphere and its wider politics of mixing. The final section offers some concluding reflections.

\section{Moral geographies of youth, gender, religion and the post-war city}

The study of moral geographies is concerned with ideas about the (often perceived) behaviour and conduct of different individuals and social groups in different spaces and how these ideas impact upon experiences of belonging and in/exclusion (e.g. Cresswell 1996, 2005; Driver 1988; Matless 1998). In previous work, I have explored how moral geographies were embedded in the contours of British uniformed youth movements, primarily through their ideological construction of duty-bound 'good citizens' to unify and distinguish between different groups of young people and their behaviour (Mills 2014). A whole body of scholarship on childhood and youth has traced how young people have been framed within certain discourses - for example trouble and risk - that creates a wider moral landscape of childhood (e.g. Aitken 2001; Stainton Rogers 2004; Valentine 1996; Massey 1998). In Britain, these ideas were arguably at their most powerful in the post-war period following the emergence of various youth sub-cultures and the advent of the 'teenager' - a figure usually associated with the urban cityscape (Bugge 2004; Cohen 1973; Hall and Jefferson 1976; see also Mills 2014). Rather than provide another historical account of youth sub-cultures in postwar Britain, this paper is an attempt to uncover how an established youth organisation - the 
JLB \& C - responded to post-war 'youth culture' and the changing leisure practices of young people in the city of Manchester (on local youth clubs, cultures of leisure and the post-war period see Clements 2016). Specifically, this present paper highlights the shifting moral geographies surrounding youth, religion and gender during the late 1950s and 1960s using the example of the JLB \& C - a uniquely gendered and religious space introduced earlier in this paper. The relevance of historical geographies of youth, religion, and gender has been demonstrated by David Harvey, Catherine Brace and Adrian Bailey’s work on Methodism in Cornwall during the nineteenth century. Although a different time period to this present discussion, the researchers importantly located young people within this wider religiousmoral landscape (e.g. Harvey et al. 2007). However, there still remains little historical geographical scholarship on the dynamics of youthful religiosities (Hopkins et al. 2011) across different time-periods, or how these intersect with other aspects of social difference, for example gender or nationality (for contemporary examples of such studies, see Hopkins 2007; Dwyer 1999, Kong 2005).

Despite the formal politics of religion and gender in the membership criteria of the JLB \& C, it is important to stress that the JLB \& C was a meeting space for diverse groups of young people. To some extent, this paper discusses how Stanley Rowe in his employment as a professional youth worker encouraged members of the JLB \& C to bring visitors- both male and female non-Jews - into the Club, creating what could be seen as a space for urban crosscultural 'meaningful' contact and encounters. There have been lively and thought-provoking debates on these ideas in social and cultural geography over the last few years, exploring what Gill Valentine has described as the "implicit role of shared space in providing the opportunity for encounters between strangers” (2008: 323; see also Valentine and Sadgrove 2014; Wilson 2011, 2013). To fully explore these ideas from historical data and evidence is, 
however, methodologically problematic. It is difficult to gauge the impact of such encounters and the extent to which they were meaningful from the historical record due to the representational politics of the archive (e.g. Gagen 2001). Therefore, this paper focuses on the moral geographies of youth, religion and gender that can be read through the archive both in adult accounts and through those written by young people themselves. The above methodological challenges do not mean, however, that the idea of an 'encounter' is not useful as a conceptual lens to consider how moral geographies come to be shaped, understood, regulated and politicised. The encounters between different groups of young people 'mixing' at the JLB \& C are significant in terms of the 'ripples' they created within the Anglo-Jewish community, as well as in young people's everyday lives. The paper therefore provides a historical example of young people’s encounters with 'difference' to compliment work in this vein on young people's spaces within social and cultural geography (e.g. Hemming 2011; Wilson 2014).

It was precisely because the JLB \& C was a site for such mixed 'encounters' between Jewish and non-Jewish young people that it often found itself at the centre of polemical debate, especially with regard to sex and marriage discussed in this paper. As hinted in the introduction, this article charts the period where the JLB \& C faced the challenge of creating, blending and sustaining two 'atmospheres'. Source material from this time names and describes a carefully managed "adult" atmosphere that could compete with the post-war city’s leisure spaces alongside a respectful and supportive "Jewish" atmosphere. The ways in which these particular atmospheres were understood, experienced, and in some cases manufactured, speaks to recent debates on atmospheres in human geography (e.g. Anderson 2009; Finn 2016). This literature seeks to engage with how certain ideologies or discourses are felt. In his work on atmospheres of 'progress' at a contemporary school in Northern England, Matt Finn refers to the individual and collective feeling of something "more fragile, 
more fleeting” (2016: 4) than emotions or ethos, whereby people become attuned to and experience a particular atmosphere in place, for example in his research within the classroom. Although this article on the JLB \& C does not go as far as aligning with work on atmospheres in relation to affective encounters (e.g. Ash 2013), I do understand atmospheres to be more than simply the 'qualities' of an environment and the discursive construction of space. In my close reading and analysis of the archival material, it is clear that the prevalence of references to 'atmosphere(s)' are not just descriptors or naming devices, but a way that adults and young people tried to make sense of the spaces around them in the post-war city, an attempt to capture some of the anxieties, emotions and feelings surrounding cultures of leisure at that time. This present paper therefore illustrates how the language and idea of atmospheres played a vital part in the construction and regulation of a moral geography surrounding youth, gender and religion at the JLB \& C and the post-war city more broadly.

This paper draws on archival fieldwork undertaken at the University of Southampton Library \& Archives using the JLB \& C's official records as well as Stanley Rowe's own personal collection and papers. Further source material was consulted at the Manchester Jewish Museum and the Manchester County Records Office. A wealth of original written and visual material was consulted at these three sites, photographed, and then converted into an electronic database. Data was then subject to textual analysis and coded through a series of thematic guides on youth, religion, gender and other project themes. The names of all young people in source material have been anonymised.

\section{“That indefinable thing”: Manufacturing and sustaining atmospheres}


Before exploring the series of debates surrounding mixing at the JLB \& C, we must first come to understand how a 'Jewish' atmosphere was imagined or originally seen to exist in this youth work space. The JLB \& C Annual Report for 1957-1959 describes how:

"It is not easy always to say what is "noticeably Jewish", or how "Jewish surroundings" can be created. In general terms they demand the provision of spiritual, cultural and even physical activities. It means the encouragement to teen-agers to think about their Judaism, what it means to them, and how they can apply it. It asks for that indefinable thing, a Jewish "atmosphere". 3

Whilst 'indefinable', there were concerted efforts by Club trustees, volunteers and even nonJewish Club Leader Stanley Rowe to create or foster this atmospheric environment at the JLB \& $\mathrm{C}$ - through discussion groups, the structure of the Jewish calendar, and the input of Rabbis. However, the appointment of Rowe as a professional trained modern youth worker to work alongside and manage volunteers (see Mills 2015 on these themes) does suggest that the Club Trustees felt an atmospheric 'Jewish' environment was no longer enough to sustain the organisation's popularity and future in the face of emerging competitors. There was a growing awareness that the 'modern' atmosphere of the post-war city and its alternative leisure spaces were luring young people away from the JLB \& C's spiritual cultural and physical activities. Once in post, Rowe tried to emulate or 'stage' the feel and atmosphere of coffee bars and beat clubs at the JLB \& C by changing the interior design and diversifying the Club's activities, for example hosting dances (discussed later in this paper). The membership grew exponentially under Rowe’s leadership, and yet archival material suggests that the JLB \& C still lacked a certain kind of 'atmosphere' compared to other leisure spaces in the city. Rowe remained acutely aware of this throughout his tenure, for example in 1966 he commissioned two volunteers to write a report on town coffee bars and beat clubs, which concluded:

“Things like 'atmosphere' and being 'with it' are of importance to many teenagers; older ones do not like mixing with younger ones; for some, contact with adults and organised 
activities hold no attraction...The JLB and Club may appear in the eyes of these young people as being dated, almost, we venture to say, quaint. Several people seemed to speak almost affectionately of the old place". ${ }^{4}$

These nostalgic overtones were worrying to the Club, and Rowe continued to try and emulate the ambiance and atmosphere of these places whilst seeking to retain the wholesome Jewish 'feel' of the JLB \& C's character. In that same report, it is not surprising that these coffee bars and beat clubs were also described in terms of atmosphere. Here, we are introduced to the 'Can-Can' bar, named after the fast-paced provocative dance associated with French cabaret:

"The atmosphere here is French and fairly intimate, with dimly-lit alcoves and Parisian scenes on the walls. The juke box plays almost continuously. Meals and drinks are served at comparatively expensive prices, but the majority of customers drink only coffee or CocaCola”5

The report continues that "the Can-Can was particularly popular with the older teenagers who wished to meet their friends in a more adult atmosphere” ${ }^{6}$. This reference to an adult atmosphere can be interpreted multiple ways, but my reading of the term is 'adult' as opposed to 'childish'. It was exactly this 'adult' atmosphere that Rowe was trying to recreate at the Club - through measures introduced here and explored in the next sections. However, these attempts at becoming more 'adult' (and by extension modern) implied something potentially less wholesome or less innocent (on these moral connotations of childhood, see Valentine 1996). These associations were therefore deeply troubling to some in Anglo-Jewry, especially some parents and Rabbis. Overall, the activities discussed in the next three sections demonstrate how the Club acted as both a mirror to the wider social changes of the post-war era, but how it was also an active contributor in shaping those same processes of social change. 


\section{Mixed-faith encounters: 'welcome' or 'undesirable' visitors}

Rowe was incredibly keen that members of the JLB \& C mixed with other young people outside of the Jewish community. He organised periodic visits between Jewish and nonJewish youth clubs in Manchester as well as inter-club socials in Leeds, Liverpool and London, with the former Club Leader described in one obituary as "encouraging Jewish young people to mix outside their own community". ${ }^{7}$ Young people would also invite their non-Jewish friends and neighbours to Club nights and there would be 'ad hoc' teenage leisure seekers who called at the JLB \& C on the way to or from the city's coffee bars, dance halls, train station, or cinemas. These mixing practices were complicated however by the realities of being affiliated to a national denominational religious organisation. At the time of its foundation in the late nineteenth century, the national Jewish Lads’ Brigade was staunchly segregated. Although there was some relaxing of this policy during the Second World War, the presence of non-Jewish youth at the JLB \& C in Manchester during the 1950s and 1960s sparked much debate.

Jewish youth mixing with non-Jewish visitors was perceived by some parents and Rabbis as a potential threat to young people's religious identities. These anxieties can be seen in an anonymous letter sent to a Jewish periodical in 1966:

"Such clubs and organisations have been and still are an asset, providing that all members are Jewish...The harm is done by undermining parental authority, as, for example by... allowing young people to hear views on religion by a non-believer. They, too, start to disbelieve and soon reject everything taught at home.”8

This letter went on to issue a warning over the role of youth clubs in providing careers advice and promoting 'independence', arguing that:

"when interference from outside is stopped, the fifth commandment will start to mean something again and the family and home will become dear, as they were in former years. Then, and only then, will immorality and other evils disappear." 
These types of nostalgic and polemical responses were isolated, yet reveal some of the wider societal tensions within the Anglo-Jewish community in post-war Britain around the sustainability of youthful religiosities and emerging competitors to domestic and family life (Hopkins et al. 2011). However, some sections of the Anglo-Jewish community welcomed the idea of more mixing in order to foster religious tolerance and combat accusations of ghettoization. Some adults even suggested that a percentage of non-Jews should be allowed into Jewish clubs as "surely the more we mix with non-Jews the less ignorance there will be about our religion”. ${ }^{10}$ An 'inter-faith' JLB \& C was, for some, viewed as a reason to be hopeful and a glimpse of a more progressive post-war urban experience.

The archival material also gives an insight into how young Jewish members of the Club talked about non-Jewish visitors. These accounts were mainly positive, for example in 1959 the youth-run magazine Club Reporter stated that "the club has been very happy to welcome a non-Jewish boy, a friend of Simon Rosenburg, who is over here with Simon's fathers firm to learn about our business methods”. ${ }^{11}$ However, we also read about less 'wholesome' youth than Simon's budding entrepreneur friend trying to access the site. At a Club night in 1963, Rowe recalls that "a group of motor bike non-Jewish boys called...I told Sheila to invite them in and show them around". ${ }^{12}$ This demonstrates Rowe's role in opening up the space of the JLB \& C to (alternative) visitors. However, young people's own accounts reveal some underlying class-based stereotypes about 'troublesome' and 'respectable' youth. For example, another edition of the Club Reporter from 1959 stated “'teddies” [Teddy Boys ${ }^{13}$ ] upset and disorganise the club...the more respectable boys and girls do not mix with them." 14 This brief quote demonstrates that young people, not just adults, constructed ideas about 'risky' youth subcultures and fed associated moral panics (Cohen 1973). Here, the disorganised bodies of 'teddies' were seen as disruptive, upsetting and ultimately 'out of place' (Cresswell 
1996). This example highlights how the moral geography of the Club was inseparable from the wider moral geography of youth in post-war Britain.

Overall, debates about inter-faith encounters at the JLB \& C echoed some wider tensions across the city and beyond about integration, assimilation and religious identity. However, running alongside these fears were a series of gender-based concerns about mixing, to which the paper now turns.

\section{Mixed-sex encounters: dances and desire}

First and foremost, during the post-war period the JLB \& C was an increasingly popular space for Jewish youth to meet members of the opposite sex of the same faith - for friendships, fleeting encounters, and long-term unions. The Club Reporter regularly contained love poems between Jewish members, tales of residential trips with "exchange visits” between boys and girls dormitories ${ }^{15}$, and tid-bits of gossip:

"ELAINE is still going steady with MICHAEL as is SIMON and ANNETTE and JULIE and HARRY...Dawn Clarke is believed to be a flirt" ${ }^{\text {" }}$.

Despite these seemingly trivial flirtations and love stories, Rowe was regularly consulted by Club members about relationships and sexual encounters, reporting after a Club night in 1963 that:

"David then wanted to talk to me - it appears that he had had intercourse...last night and was afraid that something would happen. Could he get any pills - could she do anything - would she be pregnant. From talking to boy it was clear that he knew little about sex and conception - I explained details and facts to him.”17

The Club trustees did try to regulate 'courtship' behaviours inside the Club walls, for example introducing policies that boys entering the girls' toilets would be suspended. ${ }^{18}$ Fears about encounters in toilets and other spaces of the Club became more pronounced with the 
increased presence of non-Jewish visitors discussed in the previous section. The focal point for these debates on inappropriate mixing centred on dances, a popular activity under Rowe's tenure that young people described as creating a 'better atmosphere' at the Club. ${ }^{19}$ One noteworthy dance controversy surrounded an inter-function held between the JLB \& C and a non-Jewish youth club in Manchester in 1958. Complaints in the press, recorded in committee minutes, expressed fears over the potential of dancing to lead to immoral behaviour and that "as we had a non-Jewish Warden [Stanley Rowe] he could not possibly be aware of the dangers from such inter-functions”. ${ }^{20}$ Rowe's suitability as a guardian had been questioned, but he defended the joint event stating it had "been arranged in accordance with our policy of meeting non-Jewish Clubs" and that there had been a preliminary visit to "make sure that their members would mix comfortably with ours and vice-versa”. The conclusion of a lengthy committee debate was that "whilst these inter-functions with non-Jewish Clubs were desirable and should be encouraged, dancing should not take place”. ${ }^{21}$ Here, young people of different faiths mixing was framed as 'desirable', but the gendered mixing and embodied practice of dancing was seen as troublesome (on the politics of dance and mobilities, see Cresswell 2006). In light of this controversy, some Jewish parents again stepped in to defend young people "all mixed together", noting that this should not be a worry as "Jewish boys and girls are going to non-Jewish schools and mixing with non-Jews there”. ${ }^{22}$ Perhaps the underlying reality for parents was that if young people did not mix at the JLB \& C where there was supervision and support, they would (and were) doing so elsewhere.

We see snapshots of these encounters outside the Club walls through the assignments that Rowe set for his own trainee youth workers. These University students were tasked with attending local coffee bars and reflecting on young people's social habits in notebooks. This material therefore maps out some of the everyday encounters and mobile practices of 
teenagers across the city of Manchester - with those named in these accounts known to the trainee youth workers as either JLB \& C members or visitors. Here is an extract from a report on 'The Bridge' coffee bar in 1964 that captures an unwanted encounter (or assault), but also still makes reference to the quality of this leisure space’s atmosphere:

"Richard came in for a coffee, with his newly acquired girl friend Brenda, who used to come in with two other girls and is known as a 'communal' (a girl who goes to bed with any boy)...[Jane] speaks to one or two of the boys and knows how to handle them. For instance, her cardigan was gaping and showing her bra, so Jonathan tried to poke his finger in the gape, but she slapped him across the face with such ferocity, that Jonathan just stood aback and didn't bother with her again for the rest of the evening. During the evening there were about 30 people who attended the coffee bar. The behaviour was quite good with an atmosphere to equal it."23

Rowe's trainee youth workers were visiting other spaces in the city as part of their formal education, and yet, there is an element of surveillance underlying this account that is somewhat troubling. Despite the fact there is no archival evidence to suggest these accounts were used for anything other than assessed coursework, they form part of this wider moral geography of the JLB \& C as an institution where adults were interested in the behaviours and practices of young people. Through such exercises, it does appear that Rowe's volunteer base became acutely aware of how some young people regulated courtship and managed sexual advances themselves, without adult intervention or policies about toilets. The realities of life back at the Club were thus shaped by the adult volunteers who varied in their responses: choosing to permit or punish the 'mixed' meetings they discovered. In sum, the dynamics of the JLB \& C exceeded attempts at fixity by the trustees and religious leaders, and were shaped by a range of actors, including young people themselves.

This section concludes by highlighting how the 'mixed' activities of Jewish youth in Manchester had far reaching consequences and sparked national debate. One noteworthy incident was the claim by Mrs. Weissler - Secretary for the Jewish Marriage Education Council - that there was a direct link between mixed youth clubs and the rise in unmarried 
mothers, stating in 1966 that teenagers mixing "could and frequently did, lead to petting, which was the first step to even greater immorality”. ${ }^{24}$ A joint letter of response from a number of youth workers defended their training, critiqued the use of statistics made by the Council, and argued that "although petting may be considered dangerous by some, it is not generally accepted in society as being immoral”. ${ }^{25}$ An anonymous Jewish teenager hit at the heart of the debate in terms of the contradictory and hypocritical opinions on mixing:

"To say that these clubs lead to unmarried mothers is like saying that car showrooms lead to accidents...Which is better, for us to congregate on street corners where petting and even greater immorality occurs or to meet in the friendly atmosphere of a youth club under the supervision of youth leaders? Mrs W seems to want us to segregate completely until we are about to marry. Well how can we marry if we are kept apart from the opposite sex during adolescence?". ${ }^{26}$

The next section of this article focuses explicitly on the dynamics of marriage and intermarriage - a fear that combined both types of 'mixing' discussed in the paper thus far.

\section{Mixed-marriages: the most intimate of meaningful encounters?}

The JLB \& C Trustees, staff and volunteers acknowledged that the Club was a meeting space for young people and potential love interests, despite their struggles to contain and manage relationships. For many Jewish parents the JLB \& C was deemed an 'acceptable' space for their children to attend as it had the potential for meeting an appropriate future wife or husband of the same faith. Whilst there were several motivations for attending the JLB \& C noted by young people in documentary material - to have fun with friends, see a band, learn a new sport, dance - meeting a potential partner was also recorded. Rowe seemed very aware of this, and was there to support young people with such transitions, organising visiting speakers to talk about 'Boy and Girl Relationships' and 'Relations between the Sexes'. ${ }^{27}$ Former Club members also returned to give talks about their married lives, such as $\mathrm{Mr}$ and Mrs Phillips, who "attracted a large audience when they talked about the adjustments of 
marriage... a group of girls hope to visit their home to discuss how and why they furnished in the particular way they did." 28 While this sounds very conservative and draws on feminised domestic constructions of home-making, it is worth remembering that at the same time, the Club was hosting talks on diverse progressive career opportunities for women. Here, we see a tension between the Club as a preparation space promoting the traditional and moral values of being a good (Jewish) wife and mother, whilst also part of the emergence of second-wave feminism and precursor to feminist youth work (Spence 2014).

Rowe and his volunteers simultaneously celebrated the 'success' of Club members who found love at the JLB \& C and supported young people dealing with break-ups (of their own and those of their parents). Relationships appear to have been the main driver in shaping Club membership and retention rates, with Rowe recording to the management committee in 1963 that:

\begin{abstract}
"Many of these [young people]...left because they were courting...When these romances have broken up, the Club has been able to help when the personalities involved have wanted to return. It can also be seen from this [tally chart] that many members, both boys and girls, are engaged within a year of leaving the Club”. ${ }^{29}$
\end{abstract}

Within the JLB \& C archival material, there is a tone of genuine celebratory delight in the recording of engagements, weddings and christenings that all stemmed from the JLB \& $\mathrm{C}$ as a 'meeting space', with Rowe's own notebooks full of engagement announcements and wedding invitations. This key transition to adulthood in the 1950s and 1960s was also shared with Rowe through more intimate, personal communications with their youth worker - as this letter from a former Club member who moved to the US demonstrates:

“A week from Saturday, the $5^{\text {th }}$, I'll be married. Yes, it's a fact. She's a lovely girl (yes, kosher) who went to a college very near mine. I guess I'm writing because I really feel myself changing. Marriage was always something that you 'got' when you were older. And now I am here. It's very strange to step into that image that was always so distant." 30 
Although the Club was the catalyst for countless celebrated Jewish-Jewish relationships, there is some archival material that suggests it also acted as a more accepting and 'safe' space to celebrate relationships that were ostracised and outcast at home. For example, Rowe received a signed postcard from Gretna Green ${ }^{31}$ signed by two young people with the line 'Guess What!'. Whilst it is impossible to know the future trajectories of some of these mixed marriages that originated at the JLB \& C, it is possible to suggest that this youth club was, for some people, the first step towards the most intimate of 'meaningful encounters'. Rowe listened to young people’s dilemmas surrounding intermarriage ${ }^{32}$ at a time when anxieties in the Anglo-Jewish community about 'marrying out' were prevalent (Cohen-Sherbook 2003). For example, the Club Leader noted a discussion with a boy who "talked of his non Jewish girl friend and of the difficulties it may bring”. ${ }^{33}$ There were also examples of young people disclosing the intermarriages of parents or siblings to Rowe. Fifteen year old Deborah confided that:

"My parents are divorced - years ago - my mother married young - to a nonJew.... Gran, aunty and my mum live with me at home...they are always digging up my dad - I still see him I like him - but I am never allowed to forget what he was supposed to be like... - they are always at me - about my friends - about when I go out - where I go and so on - my brother he's married out - I like his wife and I talk to her a lot. There was a fuss when they got married but it's over now...”. ${ }^{34}$

Here, the politics of faith and intermarriage - of both her mother and brother 'marrying out' has had a significant impact on Deborah's own teenage years: family tensions have seemingly constrained her mobility and leisure practices within the post-war city and also shaped her views about 'difference’ (on encounter and family life, see Valentine et al, 2015). Overall, the politics of (inter)marriage is another example of how the Club acted as both a mirror to the wider social changes of the post-war era, but was also an active contributor in 
shaping those same processes. As this paper draws to a close, I use the concluding section to reflect on this paper's discussion and future research avenues.

\section{Conclusions}

This paper has used the case-study of the JLB \& C in Manchester to explore the wider moral geographies of youth, religion and gender in post-war Britain. The paper has examined a number of debates about mixing that occurred during a time when this youth work space was striving to manufacture and blend two distinct and potentially incompatible atmospheres. Indeed, this paper's analysis has illustrated that the JLB \& C tried to walk a tightrope between promoting a form of Liberal Judaism able to include mixed-sex activities that would attract the modern teenager, but in so doing, espoused freedoms that were troubling to some parents, Rabbis and the Jewish national press. The 'immoral' consequences of mixing, promiscuous behaviour and the potential for intermarriage were seen to pose a threat to the dilution of Jewish identity. The paper has demonstrated how fears and anxieties coalesced around specific atmospheres (i.e. a 'modern' or more 'adult' atmosphere), practices (i.e. dancing, sexual acts) and spaces (i.e. the dancefloor or Club toilets) rather than the presence of certain individuals, sub-cultural groups or 'folk devils' (Cohen 1973). We can however see an alternative approach by some adults to embrace the inter-faith or mixed encounters of youth in the post-war city. Some, including Rowe, saw the potentially transformative role non-Jewish visitors could have in improving community relations through inter-faith dialogue. In sum, the JLB \& $\mathrm{C}$ has provided a useful case-study for mapping the terrain of shifting ideas about youth, religion and gender in the post-war city and illustrated how a moral geography shaped and policed particular subject positions. Here, I reflect on two potential themes for future research building on this paper's discussion. 
First, this paper has hinted at the role of visitors to the JLB \& C for creating inter-faith moments of encounter. The idea of the 'visitor' or visiting practices usefully raises a series of questions about hospitality and in/exclusion currently being theorised in urban studies (e.g. Koefoed and Simonsen 2011; Wilson 2011; Valentine \& Sadgrove 2014). Whilst the historical nature of this paper and data available has limited the extent to which the conceptual idea of the 'visitor' could be fully explored, I want to use this conclusion to suggest that the visitor has been a somewhat neglected figure in geography and social theory (compared to the 'stranger' e.g. Ahmed 2000, Hopkins 2014 or the 'neighbour' e.g. Painter 2012) and that the visit could offer a useful conceptual mid-way point between the existing domains of work on the geographies of encounter to consider 'meeting spaces'. On the one hand, a visit to a new space or environment is often, through the extension of an invitation, more structured than the haphazard or chance encounters in a café, street or bus that have characterised one reading of urban life as a series of ephemeral civil exchanges or 'throwntogetherness' (Amin 2006; Laurier and Philo 2006). Yet on the other hand, visits can be less engineered and orchestrated than projects that are designed to create deliberate structured encounters with (usually inter-faith or inter-ethnic) difference under the guise of fostering social interaction (Mayblin et al, earlyview; Matejskova and Leitner 2011; see also Wilson 2013). As events that operate somewhere between these two landscapes of encounter, visits are usually temporary, one-off and ad hoc. There is therefore scope for geographical research to further consider how visiting an(other) space, community or group has the potential to be an event of social exchange, collision, bonding, rupture, contestation or hopefulness.

Second, and finally, I end this paper with some reflections on the contemporary dynamics of youth organisations in relation to religion and gender. The national Jewish Lads' and Girls' Brigade is still active across the UK as a fully co-educational space, but one that has retained 
its religious identity or 'atmosphere' as part of an increasingly competitive landscape of ‘extra-curricular activities’ (Holloway and Pimlott-Wilson 2014). Other youth organisations, such as the Scout Association, have become increasingly 'fuzzy' or secular (or at least less overtly Christian) in an attempt to welcome those from non-Christian faiths (Mills 2012) and are now fully co-educational. Interestingly, Girlguiding UK is re-positioning itself as a single-sex feminist space of youth work and a secular youth organisation that has removed any reference to a Deity in its Promise for new members. This shifting landscape of youth organisations in relation to religion and gender therefore demonstrates how powerful these axes of social difference remain in the creation and maintenance of spaces designed for young people. These (and other) youth organisations have diverse histories, yet their identity politics and everyday practices remain firmly connected to moral geographies that are worthy of far closer attention.

\section{Acknowledgments:}

This project was supported by an RGS-IBG Small Research Grant [SRG2.12] and through access to collections at the University of Southampton Archives \& Library, Manchester Jewish Museum and Manchester County Records Office. Thanks to Sophie Cranston and Rhys Dafydd Jones for comments on an earlier version of the manuscript, and the four anonymous reviewers. Thanks to Catherine Waite for her support with coding data. This paper was originally presented at the University of Nottingham as part of the School of Geography's Cultural and Historical Geography Research Seminar Series, and featured as part of a keynote address at the 2015 ICHRE History of Education Conference at the UCL Institute of Education, London.

\section{References}

Ahmed S, 2000, Strange encounters: embodied others in post-coloniality (Routledge, London)

Aitken S C, 2001, Geographies of Young People: The Morally Contested Spaces of Identity (Routledge, London)

Amin A, 2006, “The good city” Urban Studies 43 1009-23

Anderson B, 2009, “Affective atmospheres” Emotion Space and Society 2 77-81 
Ash J. 2013, "Rethinking affective atmospheres: technology, perturbation and space times of the non-human” Geoforum 49 20-28

Bugge C, 2004, "Selling Youth in the Age of Affluence: Marketing to Youth in Britain since 1959”, in An Affluent Society? Britain's Post-War Golden Age Revisited Eds L Black and H Pemberton (Ashgate, Aldershot) pp. 185-202

Bunt S, 1975, Jewish Youth Work. Past, present and future (Bedford Square Press, London)

Clements C, 2016, Youth Cultures in the Mixed Economy of Welfare: Youth Clubs and Voluntary Associations in South London and Liverpool 1958-1985 Unpublished PhD Thesis, University of Kent

Cohen S, Folk Devils and Moral Panics (MacGibbon and Kee, London) 1972.

Cohen-Sherbok D, 2003, What's a nice Jewish boy like you doing in a place like this? (O Books, Winchester)

Collins M, 2003, Modern Love: An Intimate History of Men and Women in TwentiethCentury Britain (Atlantic Books, London)

Cresswell T, 1996, In Place/Out of Place: geography, ideology and transgression Minneapolis, MN: University of Minnesota Press

Cresswell T, 2005, “Moral Geographies”, in Cultural Geography: A Critical Dictionary of Key Concepts Eds D Atkinson, P Jackson, D Sibley and N Washbourne (Taurus, London) pp.128-134.

Cresswell T, 2006, “'You cannot shake that shimmie here’: producing mobility on the dance floor” cultural geographies 13 55-77

Dee D, 2009, “'Nothing specifically Jewish in Athletics?' Sport, Physical Recreation and the Jewish Youth Movement in London, 1895-1914” The London Journal 34 81-100

Driver F, 1988, "Moral geographies: social science and the urban environment in mid-nineteenth-century England”, Transactions of the Institute of British Geographers 13 275-278.

Dwyer C, 1999, "Veiled meanings: Young British Muslim women and the negotiation of difference” Gender, Place and Culture: A Journal of Feminist Geography 6 5-26

Finn M, 2016, “Atmospheres of progress in a data-based school” cultural geographies doi: $10.1177 / 1474474015575473$

Gagen E A, 2001, “Too good to be true: representing children's agency in the archives of playground reform” Historical Geography 29 pp. 53-64.

Hall S and Jefferson T, 1976 Ed. Resistance Through Rituals: Youth Subcultures in Post-war Britain (Hutchinson, London) 
Harvey D C, Brace C and Bailey A R, 2007, "Parading the Cornish subject: Methodist Sunday Schools in West Cornwall, c.1830-1930” Journal of Historical Geography 33 24-44

Hemming P, 2011, Meaningful encounters? Religion and social cohesion in the English primary school” Social \& Cultural Geography 12 63-81

Holdorph A, 2015, “'If I strive not after my own salvation, who shall strive for me, and if not now, when?' The role of religion in the West Central Jewish Working Girls' Club, 1893-1939" Women’s History Review 24 37-52

Holloway S L and Pimlott-Wilson H, 2014, "Enriching children, institutionalizing childhood? Geographies of play, extracurricular activities, and parenting in England" Annals of the Association of American Geographers 104 613-27

Hopkins P, 2007, Young people, masculinities, religion and race: new social geographies. Progress in Human Geography 31 163-77

Hopkins P, 2014, “Managing strangerhood: young Sikh men’s strategies” Environment and Planning A 46 1572-1585

Hopkins P, Olson E, Pain R and Vincett G, 2011, "Mapping intergenerationalities: the formation of youthful religiosities" Transactions of the Institute of British Geographers 36 314-327

Kadish S, 1995, 'A Good Jew and a Good Englishman': The Jewish Lads' \& Girls' Brigade, 1895-1995 (Valentine Mitchell, London)

Koefoed L and Simonsen K, 2011, “The stranger', the city and the nation: on the possibilities of identification and belonging” European Urban and Regional Studies 18 343357.

Kong L, 2005, "Religious schools: for spirit, (f)or nation” Environment and Planning D: Society and Space 23 615-631

Kong L, 2001, "Mapping 'new' geographies of religion: politics and poetics in modernity” Progress in Human Geography 25 211-233

Kyle R G, 2007, Moral geographies of The Boys' Brigade in Scotland Unpublished PhD thesis School of Geographical and Earth Sciences, University of Glasgow

Laurier E and Philo C, 2006, "Cold shoulders and napkins handed: gestures of responsibility" Transactions of the Institute of British Geographers 31 193-207.

Matless D, 1998, Landscape and Englishness (Reaktion, London)

Massey D, 1998, “The spatial construction of youth cultures”, in Cool Places: Geographies of Youth Cultures Eds T Skelton and G Valentine (Routledge, London) pp. 121 -129 
Matejskova T and Leitner H, 2011, "Urban encounters with difference: the contact hypothesis and immigrant integration projects in eastern Berlin” Social \& Cultural Geography 12 717741.

Mayblin L, Valentine G and Andersson J, earlyview, "In the contact zone: engineering meaningful encounters across difference through an interfaith project" The Geographical Journal doi: 10.1111/geogj.12128

Mills S, 2015, “Geographies of youth work, volunteering and employment: The Jewish Lads' Brigade \& Club in post-war Manchester” Transactions of the Institute of British Geographers 40 523-535

Mills S, 2014, "Youth on Streets and Bob-a-Job Week: Urban geographies of masculinity, risk and constructions of home in post-war Britain” Environment and Planning A 46 112-128.

Mills S, 2012, "Duty to God/Dharma/Allah/Waheguru: Diverse youthful religiosities and the politics and performance of informal worship” Social \& Cultural Geography 13 481-499

Olsen S, 2014, Juvenile Nation - Youth, Emotions and the Making of the Modern British Citizen 1880-1914 (Bloomsbury, London)

Painter J, 2012, “The politics of the neighbour” Environment and Planning D: Society and Space 30 515-533.

Reinharz S and DellaPergola S, 2009, (Eds) Jewish intermarriage around the world. (Transaction Publishers, New Brunswick, NJ)

Smith S, 2007, "Sex, Leisure and Jewish Youth Clubs in Inter-war London” Jewish Culture and History 9 1-26

Spence J, 2004, “Working for Jewish Girls: Lily Montagu, girls’ clubs and industrial reform 1890-1914” Women’s History Review 13 491-509

Spence J, 2014, "Feminism and Informal Education in Youth Work with Girls and Young Women, 1975-85” in Informal Education, Childhood and Youth: Geographies, Histories, Practices Eds S Mills and P Kraftl (Basingstoke, Palgrave Macmillan) pp. 197-215

Stainton Rogers R, 2004, “The Making and Moulding of Modern Youth: A Short History”, in Youth in Society: Contemporary Theory, Policy and Practice Eds Roche J, Tucker S, Thomson R, and Flynn R. (SAGE, London) pp. 1-9

Valentine G, 1996, “Angels and devils: moral landscapes of childhood” Environment and Planning D: Society and Space 14 581-599

Valentine G, 2008, "Living with difference: reflections on geographies of encounter" Progress in Human Geography 32 323-337

Valentine G and Sadgrove J, 2014, "Biographical narratives of encounter: the significance of mobility and emplacement in shaping attitudes towards difference" Urban Studies 51 19791994 
Valentine G, Piekut A and Harris C, 2015, "Intimate encounters: the negotiation of difference within the family and its implications for social relations in public space", The Geographical Journal 181 280-294

Valins O, 2003a, "Defending identities or segregating communities? Faith-based schooling and the UK Jewish community” Geoforum 34 235-247

Valins O, 2003b, "Stubborn identities and the construction of socio-spatial boundaries: ultraorthodox Jews living in contemporary Britain" Transactions of the Institute of British Geographers 28 158-175

Wilson H F, 2011, "Passing propinquities in the multicultural city: the everyday encounters of bus passengering” Environment and Planning A 43 634-649

Wilson H F, 2013, "Learning to think differently: diversity training and the 'good encounter'” Geoforum 45 73-82

Wilson H F, 2014, "Multicultural learning: parent encounters with difference in a Birmingham primary school” Transactions of the Institute of British Geographers 39 102114

\footnotetext{
${ }^{1}$ SU/MS223/A827/4/15/Manchester Jewish Lads’ Brigade and Club Annual Report, 1957-9, Jesse Broad \& Co Ltd: Manchester, 4-5

${ }^{2}$ SU/MS223/A827/4/7/1/Club Reporter, April 1959, 8

3 SU/MS223/A827/4/15/Manchester Jewish Lads’ Brigade and Club Annual Report, 1957-9, Jesse Broad \& Co

Ltd: Manchester, 4-5

${ }^{4}$ SU/MS223/A827/4/7 Report, Jewish Youth Goes to Town: A report on the 'Town' Coffee Bars and Beat Clubs, and the attitude of Jewish young people who use them S. Thomas \& M. Davies, July, 1966, 5

5 SU/MS223/A827/4/7 Report, Jewish Youth Goes to Town: A report on the 'Town' Coffee Bars and Beat Clubs, and the attitude of Jewish young people who use them S. Thomas \& M. Davies, July, 1966, 2

${ }^{6}$ SU/MS223/A827/4/7 Report, Jewish Youth Goes to Town: A report on the 'Town' Coffee Bars and Beat Clubs, and the attitude of Jewish young people who use them S. Thomas \& M. Davies, July, 1966, 2

${ }^{7}$ SU/MS223/A827/8/4/Stanley Rowe exhibition material, obituary 'privileged to learn from such a man', Judie Krebbs, $8^{\text {th }}$ January 1993

${ }^{8}$ SU/MS223/A827/5/39, Scrapbook 1966, Mixed clubs - letter by 'An Observer'

${ }^{9}$ SU/MS223/A827/5/39, Scrapbook 1966, Mixed clubs - letter by 'An Observer'

${ }^{10}$ SU/MS223/A827/5/44, Scrapbook 1968, (The mixed-clubs controversy 'over to youth’ Jewish Chronicle no date, From Normal Garber, Club Leader, NW Jewish Boys’ and Girls’ Club

${ }^{11}$ SU/MS223/A827/4/7/1/Club Reporter, $12^{\text {th }}$ November 1959, 4

${ }^{12}$ SU/MS223/A827/2/11[R], Manchester Jewish Lads’ Brigade and Club, Stanley Rowe’s notebook, $1^{\text {st }}$ October 1963, 65

13 'Teddy Boys' were a post-war British subculture drawing on stylised Edwardian 'dandies' in fashion style and American 'rock and roll' music tastes

${ }^{14}$ SU/MS223/A827/4/7/Club Reporter June and July 1959, 5

${ }^{15}$ SU/MS223/A827/4/7/1/Club Reporter, Volume 2, Issue 1, c.1957, 4

${ }^{16}$ SU/MS223/A827/4/7/2/New Club Reporter, November 1961, 16

${ }^{17}$ SU/MS223/A827/2/11[R], Manchester Jewish Lads’ Brigade and Club, Stanley Rowe’s notebook, $3^{\text {rd }}$ February 1963, 26

${ }_{18}$ SU/MS223/A827/4/1/14/Minutes of the Meeting of the Executive Committee, $26^{\text {th }}$ August 1968

19 SU/MS223/A827/1/12/Minutes of a Meeting of the Club Members' Committee, $15^{\text {th }}$ July 1970, 2

${ }^{20}$ SU/MS223/A827/4/1/17/Minutes of the Meeting of the Managers Committee, $23^{\text {rd }}$ June 1958

${ }^{21}$ SU/MS223/A827/4/1/17/Minutes of the Meeting of the Managers Committee, $23^{\text {rd }}$ June 1958

22 SU/MS223/A827/5/44, Scrapbook 1968, ‘Glad parents allowed non-Jewish boy friends’ - Jewish Telegraph Friday Jan $19^{\text {th }} 1968$

${ }^{23}$ SU/MS223/A827/10/6/Report on 'Bridge Coffee Bar' by Adrienne Stone, $10^{\text {th }}$ December 1964
} 
${ }^{24}$ SU/MS223/A827/5/39, Scrapbook 1966, Jewish telegraph 'More unmarried mothers' Mixed clubs lead to trouble - says teacher' Friday $5^{\text {th }}$ August 1966.

${ }^{25}$ SU/MS223/A827/5/39, Scrapbook 1966, 'Mixed Youth Clubs a Force for Good', Jewish Telegraph Friday August 12th 1966.

${ }^{26}$ SU/MS223/A827/5/39, Scrapbook 1966, Teenage Girls on Mixed Clubs, by JLB teenager, emphasis added.

${ }^{27}$ SU/MS223/A827/4/15/Manchester Jewish Lads’ Brigade and Club Annual Report, 1957-9, Jesse Broad \& Co Ltd: Manchester, 8

${ }^{28}$ SU/MS223/A827/4/2/Club Leaders Report to the Management Committee, July 1966

${ }^{29}$ SU/MS223/A827/4/1/17/Club Leaders Report on Membership II to the Management Committee, $24^{\text {th }}$ July 1963

${ }^{30}$ SU/MS223/A827/9/1/Correspondence from 'Smokey Joe', Cambridge, Mass to Stanley Rowe, May $24^{\text {th }} 1971$

${ }^{31}$ Gretna Green is a Scottish village close to the border with England famous for runaway weddings due to the legal differences surrounding age of marriage without parental consent.

${ }^{32}$ The term intermarriage is used in this paper as it is the term used in original source material. Other terms such as 'mixed marriage' are also used to define a marriage where one partner holds a different religious faith-based identity to the other partner. It is also sometimes used to define a marriage between partners of different racial, ethnic or social groups. On Jewish intermarriage, see Reinharz and DellaPergola 2009.

${ }^{33}$ SU/MS223/A827/2/11[R], Manchester Jewish Lads' Brigade and Club, Stanley Rowe's notebook, $1^{\text {st }}$ October 1963, 67

${ }^{34}$ SU/MS223/A827/2/11[R], Manchester Jewish Lads’ Brigade and Club, Stanley Rowe’s notebook, 31st January 1963, 24 